\title{
Study of Heterosis and Residual Heterosis for Horticultural and Biochemical Traits in Three Inter-Varietal Crosses of Garden Pea (Pisum sativum var. hortense L.)
}

\author{
Kumari Shiwani* and Akhilesh Sharma \\ Department of Vegetable Science and Floriculture, College of Agriculture, CSKHPKV, \\ Palampur H.P. (716062), India \\ *Corresponding author
}

Keywords

Garden pea,

Heterosis, Residual

heterosis,

Intervarietal

crosses, Trigenic

model

Article Info

Accepted:

12 November 2019

Available Online:

10 December 2019

\section{A B S T R A C T}

The present investigation was carried out to estimate in three intervarietal crosses namely, 'Palam Sumool $\times$ Punjab-89', 'Palam Sumool $\times$ Azad P-1' and 'Palam Sumool $\times$ Palam Priya' comprising of twelve generations for estimation of heterosis and residual heterosis for pod yield and component horticulture traits in garden pea. These twelve generations were evaluated in randomized complete block design with three replications during winter 201415 at Palampur for various yield and yield contributing traits. Economic heterosis was observed for pods per plant and pod yield per plant in 'Palam Sumool $\times$ Azad P-1' and 'Palam Sumool $\times$ Palam Priya' along with appreciable economic residual heterosis except pods per plant in 'Palam Sumool $\times$ Azad P-1'. Besides, 'Palam Sumool $\times$ Punjab-89' and 'Palam Sumool $\times$ Azad P-1' also showed economic heterosis for powdery mildew disease severity and pod length along with residual heterosis, respectively. In addition, 'Palam Sumool $\times$ Punjab-89' revealed appreciable residual heterosis over standard check ('Punjab-89') pods per plant, pod yield per plant, protein content and total sugars.

\section{Introduction}

Garden pea (Pisum sativum var. hortense L., $2 \mathrm{n}=2 \mathrm{x}=14$ ), a member of Fabaceae family, is one of the principal legume vegetable crops grown throughout the world. It is native of Mediterranean region with Near East and
Ethiopia as secondary centres. It is a rich source of protein ranging from 23-33\% (Sharma et al., 2019), slowly digestive starch, sugars and amino acids. Besides, it supplies an extraordinarily diverse health building nutrients such as vitamins, minerals and also lysine, a limiting essential amino acid in 
cereals (Sharma et al., 2019). It is eaten as fresh vegetable, pulse and processed as pickle, canned, frozen or dehydrated to consume during lean period (Sharma et al., 2019). It helps to reduce the cost of production by fixing atmospheric nitrogen (Anjum et al., 2015) and provide the advantage of low input and sustainable farming.

Garden pea is cultivated all through India especially in north-western Himalayan region, encompassing Himachal Pradesh, Uttrakhand and, Jammu and Kashmir states (Sharma et al., 2013) as off-season crop during the summer season. These conditions provide rewarding economic profits to the growers. The major factors decided by the breeders for garden pea improvement includes high yield, well filled-long-dark green-sweet pod attributes and resistance to pests and diseases. Heterosis is a universal phenomenon in crop plants. In the studies of heterosis emphasis has been given to partially or predominantly cross breeding species particularly those crops such as cabbage and cauliflower where heterosis is exploited commercially using $\mathrm{F}_{1}$ hybrid varieties. Nevertheless, increasing attention has been given to heterosis in inbreeding species, motivated in part by the possibility of developing effective means for the commercial exploitation of heterosis via $F_{1}$ hybrids and in part by the potential for utilizing yield data of $F_{1}$ hybrids and other early generation materials in allowing breeders to give priority to the most deserving crosses (Sarawat et al., 1994). Although high heterosis for yield have been reported in pea (Gautam et al., 2005and Pandey et al., 2006) but the cleistogamous nature of plants and non-availability of suitable male sterile $(\mathrm{ms})$ system, restricts its application in $\mathrm{F}_{1}$ hybrid production commercially. However, heterosis would be helpful in the prediction of potential crosses likely to give transgressive segregants. The effectiveness of breeding programme of self-pollinated crop may be considerably enhanced when selection for key characters is possible in early generations rather than later ones. The use of $F_{1}$ generation as a means of determining the potential for the production of transgressive segregants in later generation is limited in pea. Thus, it is desirable to screen a range of crosses to establish the level of heterosis which may be attainable and then to follow by seeking correlation between the performance of $F_{1}$ hybrids and inbred lines which are derived from it.

\section{Materials and Methods}

\section{Experimental site}

The present investigated was conducted at Experimental Farm of CSKHPKV, Palampur, Himachal Pradesh which is situated at an elevation of 1290.8 meters above mean sea level with $32^{\circ} 6^{\prime} \mathrm{N}$ latitude and $76^{\circ} 3^{\prime} \mathrm{E}$ longitude. The area is characterized by humid and temperate climate, having severe winters and mild summers with high annual rainfall of $2500 \mathrm{~mm}$ of which 80 per cent is received during June-September. The soil is classified as Alfisols typic-Hapludalf clay and is acidic in reaction ( $\mathrm{pH}$ 5-5.6).

\section{Experimental materials and breeding activities}

To ascertain the extent of heterosis and residual heterosis with respect to various horticultural traits, twelve generations viz., $\mathrm{P}_{1}$, $\mathrm{P}_{2}, \mathrm{~F}_{1}, \mathrm{~F}_{2}, \mathrm{~B}_{1}, \mathrm{~B}_{2}, \mathrm{~B}_{1 \mathrm{~S}}, \mathrm{~B}_{2 \mathrm{~S}}, \mathrm{~B}_{11}, \mathrm{~B}_{12}, \mathrm{~B}_{21}$ and $\mathrm{B}_{22}$ of three crosses were developed by utilizing the four diverse parents namely, Palam Sumool, Punjab-89, Azad P-1 and Palam Priya.

\section{Experimental layout}

During rabi, 2014-15, the experimental material comprises of twelve generations viz., $\mathrm{P}_{1}, \mathrm{P}_{2}, \mathrm{~F}_{1}, \mathrm{~F}_{2}, \mathrm{~B}_{1}, \mathrm{~B}_{2}, \mathrm{~B}_{1 \mathrm{~S}}, \mathrm{~B}_{2 \mathrm{~S}}, \mathrm{~B}_{11}, \mathrm{~B}_{12}, \mathrm{~B}_{21}$ 
and $\mathrm{B}_{22}$ was evaluated in Randomized Complete Block Design in three replications at the Experimental Farm, Department of Vegetable Science and Floriculture, CSKHPKV, Palampur. The sowing was undertaken by assigning single row to parents and $\mathrm{F}_{1}$ 's, four rows to each backcross generations and six rows to $F_{2}$ 's and second cycle of backcross generations. The seeds were sown keeping inter and intra-row spacing of $45 \mathrm{~cm}$ and $10 \mathrm{~cm}$, respectively in a row length of $2.5 \mathrm{~m}$. All the intercultural operations were carried out in accordance with the recommended schedule.

\section{Data collection and analysis}

The non-segregating generations consist of homologous population while segregating comprises of heterogeneous population. Accordingly, the data were recorded on 10 randomly selected competitive plants of each parents and $F_{1}$ 's, 20 plants in each backcross generations $\left(\mathrm{B}_{1}\right.$ and $\left.\mathrm{B}_{2}\right)$ and second cycle of backcross generations $\left(\mathrm{B}_{11}, \mathrm{~B}_{12}, \mathrm{~B}_{21}\right.$ and $\left.\mathrm{B}_{22}\right)$, and 30 plants in each $\mathrm{F}_{2}$ 's, $\mathrm{B}_{1 \mathrm{~S}}$ and $\mathrm{B}_{2 \mathrm{~S}}$. In the process of random selection, the border plants were avoided.

The parameters recorded were days to flowering, days to first picking, pod length (cm), seeds/pod, shelling (\%), plant height (cm), pods/plant and pod yield/plant (g). Standard statistical procedures were used to obtain mean and variance for each generation separately.

Heterosis effects were expressed as per cent increase (+) or (-) in the mean values of $F_{1}$ hybrid over the better parent or the standard check was calculated. The magnitude of heterosis and residual heterosis was estimated in relation to respective better parent (BP) and the standard check (SC) was computed by using the formula of (Hayman, 1957) and (Rao, 1980), respectively.

$\begin{aligned} & \text { Heterosis over } \\ & \mathrm{BP}(\%)\end{aligned}=\frac{\overline{\mathrm{F}_{1}-\overline{\mathrm{BP}}}}{\overline{\mathrm{BP}}} \times 100$
$\begin{aligned} & \text { Heterosis over } \\ & \text { the SC }(\%)\end{aligned}=\frac{\overline{\mathrm{F}_{1}-\overline{\mathrm{SC}}}}{\overline{\mathrm{SC}}} \times 100$
$\begin{aligned} & \text { Residual heterosis } \\ & \text { over BP }(\%)\end{aligned}=\frac{\overline{\mathrm{F}_{2}-\mathrm{BP}}}{\overline{\mathrm{BP}}} \times 100$
$\begin{aligned} & \text { Residual heterosis } \\ & \text { over the SC }(\%)\end{aligned}$

\section{Calculation of standard errors}

S.E. for testing heterosis over BP

$= \pm \sqrt{\frac{2 \mathrm{Me}}{\mathrm{r}}}=$ S.E. $\left(\mathrm{H}_{1}\right)$

S.E. for testing heterosis over the SC

$$
= \pm \sqrt{\frac{2 \mathrm{Me}}{\mathrm{r}}}=\text { S.E. }\left(\mathrm{H}_{2}\right)
$$

S.E. for testing residual heterosis over BP

$= \pm \sqrt{\frac{2 \mathrm{Me}}{\mathrm{r}}}=$ S.E. $\left(\mathrm{H}_{3}\right)$

S.E. for testing residual heterosis over the SC $= \pm \sqrt{\frac{2 \mathrm{Me}}{\mathrm{r}}}=$ S.E. $\left(\mathrm{H}_{4}\right)$

\section{Test of significance for heterosis}

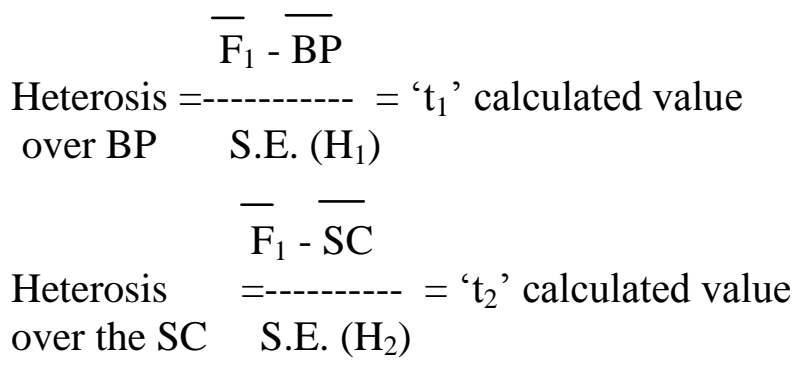


Residual heterosis over $\mathrm{BP}=$

$$
\begin{aligned}
& \overline{\mathrm{F}}_{2}-\overline{\mathrm{BP}} \\
& -----{ }^{\prime} \mathrm{t}_{3} \text { ' calculated value } \\
& \text { S.E. }\left(\mathrm{H}_{3}\right)
\end{aligned}
$$

Residual heterosis over the $\mathrm{SC}=$

$$
\begin{aligned}
& \overline{\mathrm{F}_{2}}-\overline{\mathrm{SC}} \\
& --\overline{\text { S.E. }}\left(\mathrm{H}_{4}\right)
\end{aligned}={ }^{\mathrm{t}} \mathrm{t}_{4} \text { ' calculated value }
$$

The ' $t$ ' calculated values $\left(t_{1}, t_{2}, t_{3}\right.$ and $\left.t_{4}\right)$ for heterosis over better parent (BP) and standard check (SC) and residual heterosis over better parent (BP) and standard check (SC), respectively were compared with ' $t$ ' tabulated values at error degree of freedom and $\mathrm{P} \leq 0.05$. The ' $t$ ' calculated value $\geq$ ' $t$ ' tabulated values were marked significant and an asterisk $(*)$ was put on per cent values (Dabholkar, 1992).

\section{Results and Discussion}

Exploitation of hetrosis is an easy and cheap method for increasing yield in many crops. Cross combination showing hetrotic vigour and can be utilized for developing high yielding pure lines of garden pea. Therefore in the present investigation analysis of hetrosis and residual heterosis was done for yield and component traits. However, the extent of heterosis manifested works as an indicator for the successful development of improved cultivar.

The economic heterosis was observed for pod length in 'Palam Sumool $\times$ Punjab-89' and 'Palam Sumool $\times$ Azad P-1' which was invariably coupled with highly significant economic residual heterosis in all the three crosses namely, 'Palam Sumool $\times$ Punjab-89', 'Palam Sumool $\times$ Azad P-1' and 'Palam Sumool $\times$ Palam Priya'. For powdery mildew disease severity, economic heterosis coupled with economic residual heterosis was noticed in cross 'Palam Sumool $\times$ Punjab-89'. Similarly, economic hetrosis was observed for pods per plant and pod yield per plant in 'Palam Sumool $\times$ Azad P-1' and 'Palam Sumool $\times$ Palam Priya' and that of total sugars in 'Palam Sumool $\times$ Azad P-1'. The economic residual heterosis was also observed for majority of these traits in the respective crosses except pods per plant in 'Palam Sumool $\times$ Azad P-1'.

Further, 'Palam Sumool $\times$ Punjab-89' exhibited economic residual heterosis for pods per plant, pod yield per plant, protein content and total sugars, while 'Palam Sumool $\times$ Azad P-1' showed the same for protein content (Table 1, 2 and 3). In respective studies, earlier researcher reported hybrid vigour/ heterosis with variable magnitude for pod length (Sharma et al., 2007; Thakur and Khosla, 2008; Bora et al., 2009 and Kushwah and Sharma, 2015), pods per plant (Pandey et al., 2006; Sharma et al., 2007; Thakur and Khosla, 2008; Bora et al., 2009; Karnwal and Kushwaha, 2010; Sharma and Bora, 2013 and Khushwah and Sharma, 2015) and pod yield per plant (Singh, 2005; Pandey et al., 2006; Sharma and Bora, 2013 and Sharma and Sharma, 2013).

The manifestation of residual heterosis for pod yield per plant in all the three crosses may be attributed to high residual heterosis for pods per plants, pod length and plant height in most of these crosses. These results are in close proximity to those of (Sood et al., 2006) and (Sharma el at., 2007). The presence of economic residual heterosis may be due to the dissipation of non- additive dominance effects in $\mathrm{F}_{2}$ generation.

The inbreeding depression is indirectly a manifestation of non-additive gene action controlling the characters which may required complicated breeding methodology for their exploitation or will demand exploitation of 
heterosis through hybrid variety (Sharma and Sain, 2004).

Table.1 Estimates of heterosis and residual heterosis over better parent and standard variety Punjab-89 for different horticultural and quality traits in intervarietal cross -1 (Palam Sumool $\times$ Punjab-89) of garden pea

\begin{tabular}{|c|c|c|c|c|}
\hline Cross & \multicolumn{4}{|c|}{ Palam Sumool $\times$ Punjab-89 } \\
\hline Characters & BP $(\%)$ & EH (\%) & RHBP (\%) & ERH $(\%)$ \\
\hline Days to flowering & 0.00 & 0.00 & -2.71 & -2.71 \\
\hline Days to first picking & -1.06 & -1.06 & 2.14 & 2.14 \\
\hline Pod length (cm) & $-9.09^{*}$ & $7.74^{*}$ & $-6.28^{*}$ & $11.07^{*}$ \\
\hline Seeds per pod & -5.73 & -5.73 & 7.09 & 7.09 \\
\hline Shelling percentage & 0.11 & 0.11 & $-18.45^{*}$ & $-18.45^{*}$ \\
\hline Plant height (cm) & $10.09^{*}$ & $10.09^{*}$ & 3.83 & 3.83 \\
\hline Pods per plant & -3.07 & -3.07 & $22.73^{*}$ & $22.73^{*}$ \\
\hline Pod yield per plant (g) & -3.30 & 11.39 & $22.38^{*}$ & $40.97^{*}$ \\
\hline Total soluble solids $\left({ }^{\circ} \mathrm{Brix}\right)$ & 3.47 & $8.53^{*}$ & -2.45 & 2.33 \\
\hline Ascorbic acid (mg per 100 g) & 3.45 & $8.43^{*}$ & $-5.75^{*}$ & -1.20 \\
\hline Protein content (\%) & -3.92 & 2.55 & $4.32^{*}$ & $11.34^{*}$ \\
\hline Total sugars (\%) & $-13.25^{*}$ & -8.44 & $31.50^{*}$ & $38.79^{*}$ \\
\hline $\begin{array}{c}\text { Powdery mildew disease severity } \\
(\%)\end{array}$ & $118.76^{*}$ & $-12.50^{*}$ & $113.68^{*}$ & $-14.53^{*}$ \\
\hline
\end{tabular}

"Significant at $\mathrm{P} \leq 0.05$ where, BP and RHBP- Heterosis and residual heterosis over better parent; EH and ERHEconomic heterosis and residual economic heterosis over standard variety Punjab-89, respectively.

Table.2 Estimates of heterosis and residual heterosis over better parent and standard variety Punjab-89 for different horticultural and quality traits in intervarietal cross -2 (Palam Sumool $\times$ Azad P-1) of garden pea

\begin{tabular}{|c|c|c|c|c|}
\hline Cross & \multicolumn{4}{|c|}{ Palam Sumool × Azad P-1 } \\
\hline Characters & BP (\%) & EH (\%) & RHBP (\%) & ERH (\%) \\
\hline Days to flowering & -1.12 & 2.33 & 0.37 & $3.87^{*}$ \\
\hline Days to first picking & $4.16^{*}$ & $13.60^{*}$ & $4.40^{*}$ & $13.86^{*}$ \\
\hline Pod length (cm) & -1.03 & $22.14^{*}$ & -4.92 & $17.34^{*}$ \\
\hline Seeds per pod & -4.44 & -6.00 & -0.55 & -2.18 \\
\hline Shelling percentage & -1.88 & 2.91 & 0.71 & 5.62 \\
\hline Plant height (cm) & $17.40^{*}$ & $34.75^{*}$ & $9.67^{*}$ & $25.87^{*}$ \\
\hline Pods per plant & $17.44^{*}$ & $53.06^{*}$ & -15.26 & 10.45 \\
\hline Pod yield per plant (g) & $1.60^{*}$ & $101.25^{*}$ & $-13.32^{*}$ & $33.85^{*}$ \\
\hline Total soluble solids ( ${ }^{*}$ Brix) & -4.90 & -2.68 & -3.62 & -1.37 \\
\hline Ascorbic acid (mg per 100 g) & $-9.09^{*}$ & -3.61 & -3.41 & 2.41 \\
\hline Protein content (\%) & -4.81 & -1.25 & $8.52^{*}$ & $12.58^{*}$ \\
\hline Total sugars (\%) & $9.36^{*}$ & $27.97^{*}$ & 6.43 & $24.58^{*}$ \\
\hline Powdery mildew disease severity & $300.00^{*}$ & $60.00^{*}$ & $228.84^{*}$ & $31.54^{*}$ \\
\hline (\%) & & & & \\
\hline
\end{tabular}

'Significant at $\mathrm{P} \leq 0.05$ where, BP and RHBP- Heterosis and residual heterosis over better parent; EH and ERHEconomic heterosis and residual economic heterosis over standard variety Punjab-89, respectively. 
Table.3 Estimates of heterosis and residual heterosis over better parent and standard variety Punjab-89 for different horticultural and quality traits in intervarietal cross-3 (Palam Sumool $\times$ Palam Priya) of garden pea

\begin{tabular}{|c|c|c|c|c|}
\hline Cross & \multicolumn{4}{|c|}{ Palam Sumool $\times$ Palam Priya } \\
\cline { 1 - 5 } Characters & BP (\%) & EH (\%) & RHBP (\%) & ERH (\%) \\
\hline Days to flowering & 1.10 & $6.98^{*}$ & -0.36 & $5.43^{*}$ \\
\hline Days to first picking & -2.26 & $15.46^{*}$ & $-3.84^{*}$ & $13.60^{*}$ \\
\hline Pod length (cm) & $-10.17^{*}$ & 5.58 & -2.83 & $14.20^{*}$ \\
\hline Seeds per pod & -7.20 & -17.33 & -7.04 & $-17.19^{*}$ \\
\hline Shelling percentage & $-13.10^{*}$ & -0.71 & -7.69 & 5.47 \\
\hline Plant height (cm) & $8.36^{*}$ & $26.53^{*}$ & -4.78 & $11.19^{*}$ \\
\hline Pods per plant & $-15.81^{*}$ & $53.06^{*}$ & $-32.06^{*}$ & $23.52^{*}$ \\
\hline Pod yield per plant (g) & $16.39^{*}$ & $24.93^{*}$ & $32.81^{*}$ & $42.55^{*}$ \\
\hline Total soluble solids (\%Brix) & -8.30 & -5.73 & -5.34 & -2.68 \\
\hline Ascorbic acid (mg per 100 g) & $-18.89^{*}$ & $-12.05^{*}$ & 1.25 & -2.41 \\
\hline Protein content (\%) & 2.34 & 5.04 & $-20.17^{*}$ & $-18.06^{*}$ \\
\hline Total sugars (\%) & $-13.20^{*}$ & 0.92 & $-19.86^{*}$ & -7.92 \\
\hline Powdery mildew disease & $250.00^{*}$ & $40.00^{*}$ & $187.88^{*}$ & $15.10^{*}$ \\
\hline severity (\%) & & & & \\
\hline
\end{tabular}

"Significant at $\mathrm{P} \leq 0.05$ where, BP and RHBP- Heterosis and residual heterosis over better parent; EH and ERH-

Economic heterosis and residual economic heterosis over standard variety Punjab-89, respectively.

Economic heterosis was observed for pods per plant and pod yield per plant in 'Palam Sumool $\times$ Azad P-1' and 'Palam Sumool $\times$ Palam Priya' along with appreciable economic residual heterosis except pods per plant in 'Palam Sumool $\times$ Azad P-1'. Besides, 'Palam Sumool $\times$ Punjab-89' and 'Palam Sumool $\times$ Azad P-1' also showed economic heterosis for powdery mildew disease severity and pod length along with residual heterosis, respectively. In addition, 'Palam Sumool $\times$ Punjab-89' revealed appreciable residual heterosis over standard check ('Punjab-89') pods per plant, pod yield per plant, protein content and total sugars.

Though it is not feasible to exploit heterosis directly in garden pea but combinations like 'Palam Sumool $\times$ Punjab-89' and 'Palam Sumool $\times$ Azad P-1' which were heterotic and exhibited residual heterosis could be exploited for extraction of improved pure line varieties.

\section{References}

Anjum, M., Qasim, S., Ahmad, S. and Hussain, S. (2015). Assessment of advantage of pea and non legume winter vegetables intercropping system through competition and economic indices. Experimental Agriculture, 51: 327-343 doi:10.1017/S0014479714000337.

Bora, L., Kumar, V. and Mauraya, S.K. (2009). Hybrid breeding for pod quality and components in garden pea (Pisum sativum L.). Annals of Horticulture, 2: 161-165.

Ceyhan, E., Avci, M.A. and Karadas, S. (2008). Line $\times$ tester analysis in pea (Pisum sativum L.): Identification of superior parents for seed yield and its components. African Journal of Biotechnology, 7: 2810-2817.

Dabholkar, A.R. (1992). Elements of biometrical genetics concept Publishing Company, New Delhi. P.p. 187-214. 
Gautam, G., Vidyasagar and Vermani, A. (2005). Heterobeltiosis studies in garden pea (Pisum sativum L.) Udyanika. Journal of Horticultural Sciences, 11: 97-99.

Hayman, B.I. (1957). Interaction, heterosis and diallel crosses. Genetics, 42: 336-355.

Karnwal, M.K. and Kushwaha, M.L. (2010). Studies on heterosis for pod yield and nitrogen fixing trait in garden pea under dry temperate conditions. Legume Research, 33: 50-53.

Kushwah, S. and Sharma, R.N. (2015). Study of Hybrid vigor $\left(\mathrm{F}_{1}\right)$ analysis is in vegetable pea (Pisum sativum L.). International Journal in Physical and Applied Sciences 2: 5-9.

Pandey, V., Pant, T. and Das, S.C. (2006). Studies on heterosis and combining ability in pea. Indian Journal of Horticulture, 63: 338340.

Rao, G.N. (1980). Statistics for agricultural science, Oxford and IBN publishing company, New Delhi, India. P. 467.

Sarawat, P., Stoddard, E.L., Marshall, D.R. and Ali, S.M. (1994). Heterosis for yield and related characters in pea. Euphytica, 80: 39-48.

Sharma, A., Kapoor, P., Katoch, V., Singh, Y. and Sharma, J.D. (2013). Development of powdery mildew resistance genotypes in garden pea (Pisum sativum L.) through generation mean analysis approach. Indian Journal of Genetics, 73: 371-377.

Sharma, A., Sekhon, B.S., Sharma, S. and Kumar, R. (2019). Newly isolated intervarietal garden pea (Pisum sativum L.) progenies $\left(\mathrm{F}_{7}\right)$ under north western Himalayan conditions of India. Experimental Agriculture, 1-12 doi:
$0.1017 / \mathrm{S} 0014479719000115$.

Sharma, A., Singh, G., Sharma, S. and Sood, S. (2007). Combing ability and heterosis for pod yield and related horticultural traits in garden pea (Pisum sativum L.) under mid hill sub-temperate and high hill dry-temperate conditions of Himachal Pradesh. Indian Journal of Genetics, 67: 1-6.

Sharma, B.B. and Sharma, V.K. (2013). Heterosis for earliness and green pod yield in garden pea (Pisum sativum var. hortense) under mid hill condition of Gharwal. Bioinfolet, 10: 1076-1078.

Sharma, S.N. and Sain, R.S. (2004). Genetics of grains per spike in durum wheat under normal and late planting conditions. Euphytica, 139: 1-7.

Sharma, V.K. and Bora, L. (2013). Studies on genetic variability and heterosis in vegetable pea (Pisum sativum L.) under high hills condition of Uttarakhand. African Journal of Agricultural Research, 8: 1891-1895.

Singh, G., Khokar, P.S. and Srivastava, S.B.L. (2005). Combining ability analysis for yield and yield contributing traits in field pea. Indian Journal of Pulse Research, 18: 237-239.

Sood, M., Kalia, P. and Gautam, G. (2006). Heterosis, inbreeding depression and residual heterosis for pod yield, component traits and protein content in garden pea. Indian Journal of Horticulture, 63(4): 460-463

Thakur, B.S. and Khosla, K. (2008). Heterosis and combining ability for pod yield and its component traits in garden pea. Haryana Journal of Horticultural Sciences 37: 303-306

\section{How to cite this article:}

Kumari Shiwani and Akhilesh Sharma. 2019. Study of Heterosis and Residual Heterosis for Horticultural and Biochemical Traits in Three Inter-Varietal Crosses of Garden Pea (Pisum sativum var. hortense L.). Int.J.Curr.Microbiol.App.Sci. 8(12): 1496-1502.

doi: https://doi.org/10.20546/ijcmas.2019.812.179 